\title{
INDUSTRY 4.0 CONCEPTS WITHIN THE CZECH SME MANUFACTURING SECTOR: AN EMPIRICAL ASSESSMENT OF CRITICAL SUCCESS FACTORS
}

\author{
Fortune NWAIWU(1)*, Meri DUDUCI ${ }^{\circledR}$, Felicita CHROMJAKOVA (D, \\ Cathy-Austin Funke OTEKHILE $\mathbb{D}$
}

\author{
Dept of Industrial Engineering, Faculty of Management and Economics, Tomas Bata University, Zlin, Czechia
}

Received 07 July 2019; accepted 29 October 2019

\begin{abstract}
The paper analysed factors that has the most impact in influencing the achievement of a sustainable process management model in the implementation of Industry 4.0 concepts within the Czech SME manufacturing sector. Several factors were identified and their interactions with digital technologies within the production environments was analysed. These factors, from an organisational perspective were identified as critical to success in the quest to achieve Industry 4.0 compliance and digital transformation of the manufacturing operations of companies. They include: strategy, organisational fit, competitiveness, operations and human resources. A mixed methods approach was adopted for the research. It involved both the qualitative and quantitative methodological approaches. The qualitative aspect involved an extensive systematic review of relevant literature which was useful in developing the conceptual framework and identifying the relevant factors that enable the implementation of an efficient Industry 4.0 process management model in SMEs; the quantitative aspect involved the use of a survey questionnaire to collect data which was analysed using confirmatory factor analysis statistical approach to test the measures of the constructs in the proposed conceptual framework. The result from the statistical analysis shows the factors that in the conceptual model that were supported as being relevant in achieving an efficient process management model for successful implementation of Industry 4.0 concepts in Czech manufacturing SMEs. The research limitation is based on the fact that the SMEs covered in the quantitative aspect of the research are restricted to a particular geographical location - Czech Republic. It would be interesting to have similar studies conducted in other geographies for a comparative perspective. It contributes to the scientific and practical discourse on Industry 4.0 process management model implementation in SMEs by investigating the phenomenon through the production of credible scientific evidence
\end{abstract}

Keywords: Industry 4.0, digital technologies, digital transformation, digitalisation, SMEs.

JEL Classification: O33, M10.

\section{Introduction}

Small and Medium-sized Enterprises (SME) within the manufacturing segment of industry are often faced with challenges related to achieving productivity improvements in their operations and manufacturing processes. More than often, these challenges result in budget and time overruns which in turns leaves them saddle with the prospects of lower levels of productivity, reduced competitiveness and ultimately a reduction in profitability. It has been established with empirical evidence from numerous scientific research that SMEs play an important role in the development of the economy of any country. However, due to the influences of technology and automation in the competitive business environment, SMEs that do not adapt to the requirements of technolog-ical evolution become uncompetitive (Türkeș et al., 2019). SMEs are faced with challenges in moving from their current process models to more efficient models that are in line with Industry 4.0 based technological innova-tions, some of the reasons behind the challenges faced by them include lack of funds needed to make the rele-vant investments, lack of manpower especially those related to high level information systems such as automa-tion, big data and data analytics. This is in contrast to the realities faced by larger corporations who have better resource outlays when compared to SMEs, hence making it less challenging for them in making the required transition (Lee, Bagheri, \& Kao, 2015; Lee, Kao, \& Yang, 2014).

SMEs are aware of the time in which to learn and adopt new manufacturing technologies that will bring them significant benefits in the future and help them to

*Corresponding author. E-mail: nwaiwu@utb.cz 
survive in a globalized environment (Türkeș et al., 2019). to achieve improvements to the manufacturing processes of SMEs in ways that would result in reduction in the gap existing between them and larger manufacturing companies, concerted efforts would be required in ways that are targeted at the causal factors responsible for these gaps in the first place (Lee et al., 2015). It is possible to achieve these improvements through the introduction of general purpose technologies in the category of digi-tal technologies that enable these SMEs to leapfrog barriers to become Industry 4.0 compliant in their manu-facturing and operational processes. For conceptual clarity, Industry 4.0 can be used to describe the current technological trends that are shaping the fourth industrial revolution. It is about the next stage in the organiza-tion and control of the entire value stream along the lifecycle of production technologies (Chromjakova, 2017, p. 3).

According to Ginevičius and Aleksan Ostapenko (2015, p. 130), "for a company to develop in a successful manner, it has to continuously adapt to the ever-changing environment, and to understand the potential impact of environmental factors on the performance results of the company as early as possible." This makes it im-perative for companies to take advantage of one of the readily available options of adaptation to changing business environments, which is the use of technologies. However, in spite of the growing interest in digital tech-nologies adoption and implementation in companies which leads to the concept of the "smart factory", only few SMEs within the manufacturing sector of countries around the world have been able to successfully navi-gate through the complexities and challenges of successful migration to Industry 4.0 compliance. To better understand what success means, it is imperative to establish conceptual clarity on what the terminology "critical success factors" implies. Zwikael and Globerson (2006) succinctly defines critical success factors as "the main factors that distinguish between project failure and project success." Also, "they are the limited number of areas in which results, if they are satisfactory, will ensure successful competitive performance for an organisation. Critical success factors support the attainment of organisational goals; they can also be seen as the areas in which good performance is necessary to ensure attainment of those goals" (Rockart, 1979, p. 85 as cited in Van Scoter, 2011).

There are many factors responsible for the low level of success observed, some of the notable reasons for the significantly high failure rates can be traced to lack of formalised processes, lack of ICT knowledge as well as lowcost commercial systems. Therefore, recent developments have made it imperative to have a clear under-standing of the best approach to operationalise the adoption and implementation of digital technologies in companies that would lead to Industry 4.0 compliance using strategies that would translate to positive process improvement outcomes for manufacturing companies operating at the small and medium scale enterprise (SME) level. Hence, this research aims to identify critical success factors that aid the attainment of efficient process management models compliant with Industry 4.0 concepts in manufacturing based SMEs, this will be done by addressing the research question: what are the relevant factors that enable the implementation of effi-cient process management model in SMEs that aim to achieve a higher level of Industry 4.0 compliance within their operations and manufacturing processes? The research adopts a mixed method approve which involves both the qualitative and quantitative methodological approaches and contributes to the existing body of knowledge to Industry 4.0 process management implementation in SMEs.

\section{Literature review}

The term Industry 4.0 was coined from an initiative launched by the German government for safeguarding the long-term competitiveness of the manufacturing industry in Germany. It conceptualises the integration of cyber-physical systems (CPS) in industrial manufacturing, Industry 4.0 aims at establishing intelligent, selfregulating, and interconnected industrial value creation (Müller, Buliga, \& Voigt, 2018). Industry 4.0 is driven by four clusters of disruptive technologies: the first cluster is anchored on data, computational power, and connectivity - low-power, wide-area networks are one example; analytics and intelligence from the second cluster; while human-machine interaction makes up the third, comprising, examples include, touch interfaces and aug-mented reality; finally, digital-to-physical conversion is the fourth cluster, and it covers the following - ad-vanced robotics and 3D printing are two examples (Wee et al., 2015, p. 7).

These disruptive technologies have also led to emergence of recurrent themes in regards to process management and other related practices that are well established in manufacturing industries. In relations to productivity improvements within the manufacturing processes of companies, Gilchrist (2016, p. 195) argues that Industry 4.0 will bring about improvements in the industrial processes within manufacturing as a whole, through engineering, material usage, supply chains, and product lifecycle management. However, technology adoption and implementation done in isolation of other factors and considerations has been shown by various researchers and industry practitioners not to be sufficient in attaining the objectives of achieving process improvements, waste reduction and overall profitability of companies. The main reasons can be related to the issues as diverse as the lack of formalised processes, inadequate knowledge of beneficial ICTs as well as lack of access to low-cost commercial systems (Dassisti et al., 2018; Müller et al., 2018; Sevinç, Gür, \& Eren, 2018). The table below provides (Table 1) a summary of the major definitions of Industry 4.0 that is found in academic literature.

A review of the definitions captured in Table 1 indicates that a key concept common to them is that of what is described as - Cyber-Physical Systems (CPS), which basically describes a group or collection of transformative 
Table 1. Definitions of Industry 4.0

\begin{tabular}{|l|l|}
\hline \multicolumn{1}{|c|}{ Author(s) } & \multicolumn{1}{c|}{ Definition of Industry 4.0 } \\
\hline $\begin{array}{l}\text { (Kagermann et al., 2013 } \\
\text { as cited in Ganzarain \& } \\
\text { Errasti, 2016a, p. 1122). }\end{array}$ & $\begin{array}{l}\text { Industry 4.0 is described as a collection of following seven concepts: smart factories, cyber-physical } \\
\text { systems, self-organization, new systems in distribution and procurement, new systems in the } \\
\text { development of products and services, adaptation to human needs and corporate social responsibility }\end{array}$ \\
\hline $\begin{array}{l}\text { (Senvar \& Akkartal, 2018, } \\
\text { pp. 50-51). }\end{array}$ & $\begin{array}{l}\text { Industry 4.0 is a combination of several novel technological advancements some of which are; } \\
\text { information and communication technology (ICT), Cyber-Physical Systems (CPS), network } \\
\text { communications, big data and cloud computing, modelling, virtualization and simulation ,improved } \\
\text { tools for human-computer interaction and cooperation }\end{array}$ \\
\hline (Wee et al., 2015, p. 7) & $\begin{array}{l}\text { McKinsey defines Industry 4.0 as digitization of the manufacturing sector, with embedded sensors in } \\
\text { virtually all product components and manufacturing equipment, ubiquitous cyberphysical systems, } \\
\text { and analysis of all relevant data. }\end{array}$ \\
\hline $\begin{array}{l}\text { (Pfohl, Yahsi, \& Kuznaz, } \\
\text { 2015, p. 37) }\end{array}$ & $\begin{array}{l}\text { Industry 4.0 is the sum of all disruptive innovations derived and implemented in a value chain to } \\
\text { address the trends of digitalization, autonomisation, transparency, mobility, modularization, and } \\
\text { network-collaboration and socializing of products and processes. }\end{array}$ \\
\hline (Sung, 2018, p. 40) & $\begin{array}{l}\text { Industry 4.0 is the next phase in the digitisation of the manufacturing sector, it is driven by four } \\
\text { disruptions: the astonishing rise in data, computational power, and connectivity, especially new } \\
\text { low-power wide-area networks; the emergence of analytics and business-intelligence capabilities; } \\
\text { new forms of human-machine interaction such as touch interfaces and augmented-reality systems; } \\
\text { and improvements in transferring digital instructions to the physical world, such as with advanced } \\
\text { robotics and 3-D printing }\end{array}$ \\
\hline $\begin{array}{l}\text { (Gubán \& Kovács, 2017, } \\
\text { p. 112). }\end{array}$ & $\begin{array}{l}\text { The essence of Industry 4.0 conception is the introduction of network-linked intelligent systems, } \\
\text { which realize self-regulating production: people, machines, equipment and products will } \\
\text { communicate to one another }\end{array}$ \\
\hline
\end{tabular}

technologies that manages interconnected systems between their physical assets and computational capabilities (Lee et al., 2015, p. 18). The CPS connects all physical devices to the Internet, it incorporates five functions: computing, communications, precision control, coordination and autonomy. Smart products and smart produc-tion are made possible through the integration of the virtual world and the physical world (K. Zhou, Liu, \& L. Zhou, 2016, p. 2148).

Results from a research conducted by Pfohl et al. $(2015$, p. 37) analyzed a total of 49 technologies which they identified as relevant in shaping the fourth industrial revolution, they reduced them to a group that are most relevant which fall under the following seven categories: digitalization, autonomisation, transparency, mobility, modularization, network-collaboration and socializing of products and processes. Another interesting perspective is that of Petrasch and Hentschke (2016) whose assessment of Industry 4.0 is done in terms of technological concepts classified under three broad categories: Embedded Systems (ES)/CPS (Cyber-Physical Systems), Internet/Cloud of Things (IoT/CoT), Service-Oriented Architecture (SOA)/ Internet of Services (IoS)/Cloud Computing (CC). The idea of categorization is relevant in simplifying the inquiry into the dynamics of Industry 4.0 and all related concepts such as Lean Manufacturing which is a methodology with the potential to improve productivity and decrease costs in manufacturing organizations (Sanders, Elangeswaran, \& Wulfsberg, 2016); Business Process Modelling (BPM) which describes behavioral aspects of a system and are usually on the for-mal requirements or early design level (Petrasch \& Hentschke, 2016); and Cyber-Physical Systems and how they interact with current practices such as Lean Manufacturing in improving efficiency of existing processes analysis and modelling systems.

As part of the process of extracting evidence from existing literature on the subject area, an extensive literature re-view was conducted which yielded the following observations: firstly, it was observed that a general consensus exists among the body of technological innovations upon which Industry 4.0 as a concept is anchored; secondly, it was also observed that there was a lack of a generally accepted conceptual/theoretical framework for Industry 4.0 which could serve as a guiding tool for companies interested in migrating their processes through the adoption and imple-mentation of digital technologies within their manufacturing, logistics and supply chain operations. Also, there is a lack of consensus on conceptual clarity in relations to how the term Industry 4.0 is conceptualised and defined by stakeholders both within industry and the academia, this lack of conceptual clarity results in conflict and can be said to be partly responsible for the gap observed in regards to the existence of a generally accepted theoreti-cal/conceptual framework on Industry 4.0 maturity assessment models for companies.; thirdly, the body of litera-ture on Industry 4.0 in the Czech Republic is scanty, which is an indication of the level of maturity and adoption of the phenomenon among Czech industries; fourthly, it is also observed that a vast majority of studies conducted on this subject tended to have a qualitative bias, this could also be attributed to the lack of a conceptual/theoretical framework which makes the application of quantitative methods and statistical analysis somewhat difficult at the current stage of development of the subject. 
Table 2. Summary of literature reviewed

\begin{tabular}{|c|c|c|c|c|}
\hline Author(s) & Title of study & $\begin{array}{c}\text { Research } \\
\text { Methodology }\end{array}$ & Focus area(s) & Key findings \\
\hline $\begin{array}{l}\text { Dilberoglu } \\
\text { et al. (2017) }\end{array}$ & $\begin{array}{l}\text { The Role of Additive } \\
\text { Manufacturing in the } \\
\text { Era of Industry } 4.0\end{array}$ & $\begin{array}{l}\text { Qualitative } \\
\text { research - } \\
\text { focused on } \\
\text { review of trends } \\
\text { within industry }\end{array}$ & $\begin{array}{l}\text { Additive } \\
\text { manufacturing, } \\
\text { 3D printing, } \\
\text { Smart materials, } \\
\text { Computational } \\
\text { geometry, Industry } 4.0\end{array}$ & $\begin{array}{l}\text { Comprehensive review of additive } \\
\text { manufacturing technologies is presented } \\
\text { together with both its contributions to } \\
\text { Industry } 4.0\end{array}$ \\
\hline $\begin{array}{l}\text { Sevinç et al. } \\
(2018)\end{array}$ & $\begin{array}{l}\text { Analysis of the } \\
\text { Difficulties of SMEs } \\
\text { in Industry } 4.0 \\
\text { Applications by } \\
\text { Analytical Hierarchy } \\
\text { Process and Analytical } \\
\text { Network Process }\end{array}$ & $\begin{array}{l}\text { Qualitative - } \\
\text { use of analytic } \\
\text { hierarchy } \\
\text { process (AHP) }\end{array}$ & $\begin{array}{l}\text { Industry } 4.0 \\
\text { application by SMEs } \\
\text { and difficulties often } \\
\text { encountered by them } \\
\text { in the process }\end{array}$ & $\begin{array}{l}\text { Results shows that companies contribute to } \\
\text { the determination of strategic steps, thereby } \\
\text { facilitating the transition of enterprises to } \\
\text { Industry } 4.0 \text { which leads to efficient use of } \\
\text { resources. Also, the interaction between some } \\
\text { criteria was taken into consideration re- } \\
\text { evaluated using the analytical network process } \\
\text { method. The results of the two methods } \\
\text { support each other. }\end{array}$ \\
\hline $\begin{array}{l}\text { Hofmann } \\
\text { and Rüsch } \\
(2017)\end{array}$ & $\begin{array}{l}\text { Industry } 4.0 \text { and the } \\
\text { current status as well } \\
\text { as future prospects for } \\
\text { logistics }\end{array}$ & $\begin{array}{l}\text { Qualitative } \\
\text { research }\end{array}$ & $\begin{array}{l}\text { Advanced } \\
\text { manufacturing, } \\
\text { Internet of things, } \\
\text { Cyber-physical } \\
\text { systems, Distributed } \\
\text { ledger technology, } \\
\text { Cross-company } \\
\text { Kanban, Just-in-time, } \\
\text { Just-in-sequence. } \\
\end{array}$ & $\begin{array}{l}\text { The research identifies opportunities in } \\
\text { terms of decentralization, self-regulation and } \\
\text { efficiency. It also shows that the concept of } \\
\text { Industry } 4.0 \text { still lacks a clear understanding } \\
\text { and is not fully established in practice yet. It } \\
\text { finally demonstrates potential Industry } 4.0 \\
\text { implications in the context of Just-in-Time/ } \\
\text { Just-in-Sequence and cross-company Kanban } \\
\text { systems in a precise manner. }\end{array}$ \\
\hline $\begin{array}{l}\text { Schönsleben } \\
\text { et al. (2017) }\end{array}$ & $\begin{array}{l}\text { What Benefits do } \\
\text { Initiatives Such as } \\
\text { Industry } 4.0 \text { Offer for } \\
\text { Production Locations in } \\
\text { High-wage Countries? }\end{array}$ & $\begin{array}{l}\text { Qualitative } \\
\text { research - case } \\
\text { study approach }\end{array}$ & $\begin{array}{l}\text { Industry } 4.0, \\
\text { production processes, } \\
\text { Switzerland }\end{array}$ & $\begin{array}{l}\text { Outlines concepts and examples around } \\
\text { Industry 4.0. It offers a realistic view of } \\
\text { the likely future effects of Industry } 4.0 \text { for } \\
\text { production locations in high-wage countries } \\
\text { using Switzerland as a case study. }\end{array}$ \\
\hline $\begin{array}{l}\text { Zhou et al. } \\
(2016)\end{array}$ & $\begin{array}{l}\text { Industry 4.0: Towards } \\
\text { future industrial } \\
\text { opportunities and } \\
\text { challenges }\end{array}$ & $\begin{array}{l}\text { Qualitative } \\
\text { research }\end{array}$ & $\begin{array}{l}\text { Industry 4.0, CPS, } \\
\text { CPPS, cloud com- } \\
\text { puting, big data, in- } \\
\text { telligent manufacturing }\end{array}$ & $\begin{array}{l}\text { Makes reference to the enlightenment for } \\
\text { China's manufacturing industries, to build } \\
\text { China's Industry 4.0. }\end{array}$ \\
\hline $\begin{array}{l}\text { Vrchota, } \\
\text { Volek, and } \\
\text { Novotná } \\
(2019)\end{array}$ & $\begin{array}{l}\text { Factors Introducing } \\
\text { Industry } 4.0 \text { to SMES }\end{array}$ & $\begin{array}{l}\text { Qualitative } \\
\text { research }\end{array}$ & Industry 4.0, SMEs & $\begin{array}{l}\text { They found from their analysis of } 1018 \text { Czech } \\
\text { SMEs, that the introduction of Industry } 4.0 \text { is } \\
\text { related to the size of the company. }\end{array}$ \\
\hline $\begin{array}{l}\text { Baena et al. } \\
(2017)\end{array}$ & $\begin{array}{l}\text { Learning Factory: The } \\
\text { Path to Industry } 4.0\end{array}$ & $\begin{array}{l}\text { Systematic re- } \\
\text { view - involving } \\
\text { quantitative and } \\
\text { qualitative text } \\
\text { analysis }\end{array}$ & $\begin{array}{l}\text { Learning Factories, } \\
\text { Engineering education, } \\
\text { Industry } 4.0 \text {, Active } \\
\text { Learning. }\end{array}$ & $\begin{array}{l}\text { Describes the transformation process of a } \\
\text { training-addressed manufacturing workshop, } \\
\text { in order to structure a Learning Factory for } \\
\text { the production engineering program at EAFIT } \\
\text { University. }\end{array}$ \\
\hline DIN (2016) & $\begin{array}{l}\text { German Standardization } \\
\text { Roadmap: Industry } 4.0\end{array}$ & $\begin{array}{l}\text { Qualitative } \\
\text { review }\end{array}$ & $\begin{array}{l}\text { Platform Industry } \\
4.0, \text { CPS, automation } \\
\text { systems, information } \\
\text { technology, radio } \\
\text { communication } \\
\end{array}$ & $\begin{array}{l}\text { Draw up, strategic, technically oriented } \\
\text { roadmap with recommendations from } \\
\text { the Industry and Science Research Union } \\
\text { and from BMWi and BMBF to achieve } \\
\text { standardization of Industry } 4.0 \text { Roadmap. }\end{array}$ \\
\hline $\begin{array}{l}\text { Türkeș et al. } \\
\text { (2019) }\end{array}$ & $\begin{array}{l}\text { Drivers and Barriers in } \\
\text { Using Industry } 4.0: \text { A } \\
\text { Perspective of SMEs in } \\
\text { Romania }\end{array}$ & $\begin{array}{l}\text { Quantitative } \\
\text { research }\end{array}$ & $\begin{array}{l}\text { Industry 4.0, SMEs, } \\
\text { Romania }\end{array}$ & $\begin{array}{l}\text { The research highlighted the fact that many } \\
\text { SMEs in Romania are in a transition process } \\
\text { from industry } 2.0 \text { to industry } 4.0 \text {. It also } \\
\text { found that there is a high level of knowledge } \\
\text { of Industry } 4.0 \text { technologies, and a desire to } \\
\text { implement them in the Romanian SMEs, as } \\
\text { well as the low level of resources needed to } \\
\text { implement it. }\end{array}$ \\
\hline Lu (2017) & $\begin{array}{l}\text { Industry 4.0: A survey } \\
\text { on technologies, } \\
\text { applications and open } \\
\text { research issues }\end{array}$ & $\begin{array}{l}\text { Systematic } \\
\text { review of } \\
\text { existing } \\
\text { literature }\end{array}$ & $\begin{array}{l}\text { Industry } 4.0, \text { Cyber } \\
\text { physical system, } \\
\text { Internet of things, } \\
\text { Big data, Enterprise } \\
\text { architecture, Enterprise } \\
\text { integration }\end{array}$ & $\begin{array}{l}\text { The research outlines the critical issue of the } \\
\text { interoperability of Industry } 4.0 \text {, and proposes } \\
\text { a conceptual framework of interoperability } \\
\text { regarding Industry } 4.0 \text {. Challenges and } \\
\text { trends for future research on Industry } 4.0 \text { are } \\
\text { discussed. }\end{array}$ \\
\hline
\end{tabular}


End of Table 2

\begin{tabular}{|c|c|c|c|c|}
\hline Author(s) & Title of study & $\begin{array}{c}\text { Research } \\
\text { Methodology }\end{array}$ & Focus area(s) & Key findings \\
\hline $\begin{array}{l}\text { Mrugalska } \\
\text { and } \\
\text { Wyrwicka } \\
(2017)\end{array}$ & $\begin{array}{l}\text { Towards Lean } \\
\text { Production in } \\
\text { Industry } 4.0\end{array}$ & $\begin{array}{l}\text { Qualitative } \\
\text { research }\end{array}$ & $\begin{array}{l}\text { Industry } 4.0 \text {, lean } \\
\text { automation, lean } \\
\text { production, production } \\
\text { management }\end{array}$ & $\begin{array}{l}\text { The research advised to introduce IT } \\
\text { integration of the production level with the } \\
\text { planning level. It also showed the possibility } \\
\text { of linking the two approaches of Lean } \\
\text { Manufacturing and Cyber-Physical Systems of } \\
\text { Industry } 4.0\end{array}$ \\
\hline $\begin{array}{l}\text { Meissner, } \\
\text { Ilsen, and } \\
\text { Aurich } \\
(2017)\end{array}$ & $\begin{array}{l}\text { Analysis of control } \\
\text { architectures in the } \\
\text { context of Industry } 4.0\end{array}$ & $\begin{array}{l}\text { Qualitative } \\
\text { research }\end{array}$ & $\begin{array}{l}\text { Production planning, } \\
\text { Scheduling, Planning, } \\
\text { Industry } 4.0\end{array}$ & $\begin{array}{l}\text { Conclusions are drawn about how the different } \\
\text { architectures suit Industry } 4.0 \text {, and need for } \\
\text { action for the development of production } \\
\text { controls of Industry } 4.0 \text { is derived. }\end{array}$ \\
\hline Li (2017) & $\begin{array}{l}\text { China's manufacturing } \\
\text { locus in 2025: With a } \\
\text { comparison of "Made- } \\
\text { in-China 2025" and } \\
\text { "Industry 4.0" }\end{array}$ & $\begin{array}{l}\text { Qualitative } \\
\text { research } \\
\text { supported by } \\
\text { secondary data }\end{array}$ & $\begin{array}{l}\text { Made-in-China } \\
\text { 2025, Industry 4.0, } \\
\text { Emerging economy, } \\
\text { Cyber-physical } \\
\text { systems (CPS), } \\
\text { Internet of Things } \\
\text { (IoT), Manufacturing } \\
\text { capability, Human } \\
\text { capital, R\&D, Smart } \\
\text { factory, Collaborative } \\
\text { robots }\end{array}$ & $\begin{array}{l}\text { Helps in understanding the relationship } \\
\text { between technological entrepreneurship } \\
\text { and socio-economic changes in emerging } \\
\text { economies such as China. }\end{array}$ \\
\hline $\begin{array}{l}\text { Wagner } \\
\text { et al. (2017) }\end{array}$ & $\begin{array}{l}\text { Industry } 4.0 \text { impacts on } \\
\text { lean production systems }\end{array}$ & $\begin{array}{l}\text { Qualitative } \\
\text { research }\end{array}$ & $\begin{array}{l}\text { Cyber physical } \\
\text { production system, } \\
\text { connected industry, } \\
\text { industry } 4.0 \text {, cyber } \\
\text { physical system, Lean } \\
\text { Production, technology } \\
\text { management }\end{array}$ & $\begin{array}{l}\text { Proposes a usable matrix framework with } \\
\text { potential to have an impact on lean production } \\
\text { systems within the context of Industry } 4.0 \text {. }\end{array}$ \\
\hline $\begin{array}{l}\text { Kopp and } \\
\text { Basl (2017) }\end{array}$ & $\begin{array}{l}\text { Study of the Readiness } \\
\text { of Czech Companies in } \\
\text { the Industry } 4.0\end{array}$ & $\begin{array}{l}\text { Quantitative } \\
\text { research }\end{array}$ & $\begin{array}{l}\text { Industry } 4.0, \text { Industry } \\
4.0 \text { readiness, Internet } \\
\text { of Things, } 4 \text { th } \\
\text { industrial revolution. }\end{array}$ & $\begin{array}{l}\text { It presented a result that shows the readiness } \\
\text { of Czech companies in adopting the trend of } \\
\text { Industry } 4.0 \text { in the operations. }\end{array}$ \\
\hline $\begin{array}{l}\text { Lee, Kao, } \\
\text { and Yang } \\
(2014)\end{array}$ & $\begin{array}{l}\text { Service innovation } \\
\text { and smart analytics for } \\
\text { Industry } 4.0 \text { and big } \\
\text { data environment }\end{array}$ & $\begin{array}{l}\text { Qualitative } \\
\text { research }\end{array}$ & $\begin{array}{l}\text { Manufacturing } \\
\text { servitization; predictive } \\
\text { maintenance; } \\
\text { industrial big data }\end{array}$ & $\begin{array}{l}\text { The research addressed the trends of } \\
\text { manufacturing service transformation in } \\
\text { the big data environment, as well as the } \\
\text { readiness of smart predictive informatics } \\
\text { tools to manage big data, thereby achieving } \\
\text { transparency and productivity. }\end{array}$ \\
\hline $\begin{array}{l}\text { Lee et al. } \\
(2015)\end{array}$ & $\begin{array}{l}\text { A Cyber-Physical } \\
\text { Systems (CPS) } \\
\text { architecture for Industry } \\
4.0 \text {-based manufacturing } \\
\text { systems }\end{array}$ & $\begin{array}{l}\text { Qualitative } \\
\text { research }\end{array}$ & $\begin{array}{l}\text { Cyber-Physical System, } \\
\text { Industry } 4.0, \text { Health } \\
\text { management and } \\
\text { prognostics, Time } \\
\text { machine }\end{array}$ & $\begin{array}{l}\text { The research proposes unified 5-level } \\
\text { architecture is as a guideline for } \\
\text { implementation of CPS. }\end{array}$ \\
\hline $\begin{array}{l}\text { Faller \& } \\
\text { Feldmúller } \\
(2015)\end{array}$ & $\begin{array}{l}\text { Industry } 4.0 \text { learning } \\
\text { factory for regional } \\
\text { SMEs }\end{array}$ & $\begin{array}{l}\text { Qualitative } \\
\text { research }\end{array}$ & $\begin{array}{l}\text { Automation, Energy } \\
\text { efficiency, Industry } 4.0, \\
\text { Shop floor - top floor } \\
\text { integration }\end{array}$ & $\begin{array}{l}\text { The research delivered its output in terms of } \\
\text { a learning factory with } 3 \text { different training } \\
\text { setups. It is used for the practical teaching } \\
\text { of the students and for evaluating research } \\
\text { projects. }\end{array}$ \\
\hline $\begin{array}{l}\text { Wee et al. } \\
(2015)\end{array}$ & $\begin{array}{l}\text { Industry } 4.0 \text { - how to } \\
\text { navigate digitization } \\
\text { of the manufacturing } \\
\text { sector }\end{array}$ & $\begin{array}{l}\text { A mixed } \\
\text { method } \\
\text { research } \\
\text { approach which } \\
\text { involved both } \\
\text { Quantitative } \\
\text { and Qualitative } \\
\text { methodologies }\end{array}$ & $\begin{array}{l}\text { Industry } 4.0 \text {, } \\
\text { automation, digital } \\
\text { transformation }\end{array}$ & $\begin{array}{l}\text { The findings reveal that manufacturing } \\
\text { companies should act along three dimensions } \\
\text { to capture the potential of the Industry } 4.0 \text { : } \\
\text { drive } \\
\text { the next horizon of operational effectiveness, } \\
\text { adapt business models to capture shifting value } \\
\text { pools, and build the foundations for digital } \\
\text { transformation. }\end{array}$ \\
\hline $\begin{array}{l}\text { Ganzarain } \\
\text { and Errasti } \\
(2016 a)\end{array}$ & $\begin{array}{l}\text { Three Stage Maturity } \\
\text { Model in SME's towards } \\
\text { Industry } 4.0\end{array}$ & $\begin{array}{l}\text { A collaborative } \\
\text { diversification } \\
\text { methodological } \\
\text { approach }\end{array}$ & Industry 4.0, SMEs & $\begin{array}{l}\text { The findings of their research showed a need } \\
\text { for guided support in the } \\
\text { development of a company-specific Industry } \\
4.0 \text { vision with specific project planning. }\end{array}$ \\
\hline
\end{tabular}




\subsection{Review of factors identified as relevant to the success of Industry 4.0 implementation}

Based on evidence obtained from literature (Table 2), small and medium sized enterprises (SMEs) have been identi-fied as a critical segment and major driving force responsible for good health of any economy and wellbeing of the society as a whole (Aris, 2007; Oreoluwa, 2011; Phillips \& Raby, 2017; Taiwo, Ayodeji, \& Yusuf, 2018). Within the manufacturing sector, SMEs constitute a major component, therefore, it is imperative to investigate the impact of Industry 4.0 within this segment. When compared to larger companies involved in manufacturing, SMEs are often confronted by a wide variety of challenges and barriers that make their transition to Industry 4.0 compliance often difficult or impossible (Mittal, Khan, Romero, \& Wuest, 2018). This was demonstrated in a research conducted by Müller et al. (2017) on Industry 4.0 and its impact on German SMEs, their results showed that Industry 4.0 impacts SMEs from three fundamental dimensions which are as follows: high-grade digitisation of processes, smart manu-facturing, and intercompany connectivity; second, Industry 4.0 affects the three business model elements of manufacturing SMEs - value creation, value capture, and value offer - by giving specific examples for business model innovation in each of the three elements; and finally, both the role as a user and/or provider of Industry 4.0 and whether a company is internally motivated and/or externally pressured towards implementation have an impact on which business model elements are innovated.

Strategy plays a vital role in shaping the outcomes of Industry 4.0 concepts implementation in the pursuit of effi-cient process management models, this was corroborated by the findings contained in the research by Ganzarain and Errasti (2016b), they made a case for guided support in the development of company specific Industry 4.0 vision and project planning. Also, Mittal et al. (2018) investigated how "organisational fit" influences and shapes the outcomes of Industry 4.0 concepts implementation in SMEs, results obtained from their study revealed the following outcomes: the current standard starting (base level) of most maturity models appears to be disconnected from the real digitization and smart manufacturing maturity level of many SMEs; the transition from a non-existent lower level "level 0", to the current base level, requires significant effort including a mind-set change; maturity models and readiness assessments can be associated with a Smart Manufacturing (SM) toolkit; and SMEs need to develop their own, unique SM or Industry 4.0 vision and roadmap.

Hence, evidence obtained from the extensive literature review conducted as part of this study led to the identification of several factors as having significant influence on the outcomes of implementation of the Industry 4.0 concepts in the quest of achieving an improved process management in SMEs that engage in production or manufacturing operations. From the review of relevant literature, factors identified as being strategically important to achieving Industry 4.0 compliant process management models are as follows: organisational strategy (Strategy); how the firm's strategic alignment is configured for adoption and implementation of digital technologies to fit into various organisational processes, business units or functions (Organisational fit); how these digital technologies translate to improved competitiveness for the company (Competitiveness); how digital technologies directly impact on processes such as manufacturing, supply chain, logistics (Operations); finally, the human resource availability and readiness within the company (Human resources), these set of factors are considered to be quite influential in determining overall outcomes (Chromjakova, 2017; Faller \& Feldmúller, 2015; Ganzarain \& Errasti, 2016b; Müller et al., 2017; Rodič, 2017).

Therefore, a conceptual framework is proposed in this study, and it take the following factors into consideration as being relevant to a company achieving the desired process management model for Industry 4.0 implementation in their processes that covers their business model, operating model, customer engagement strategy and their value propositions. Hence, the following hypothesis are proposed as the basis for a quantitative assessment of the pro-posed conceptual framework.

Strategy: various researchers have tried to relate the role of strategy in achieving sustainable growth and profitability for companies (Porter \& Kramer, 2006; Schumacher, Erol, \& Sihn, 2016; Wiersema \& Bantel, 1992). In relations to how strategy impacts on successful implementation of Industry 4.0 based process management model in SMEs, Fettig et al. argue that "implementing an Industry 4.0 process management strategy can lead to more autonomy, enrichment of functions, new and more flexible organizations that enable the development of individual skills and create opportunities for a better work-life-balance." Therefore, to test the validity of this statement, a hypothesis is proposed as follows:

H1: Developing and implementing the right corporate and organizational strategy positively impacts the outcomes for achieving an efficient process management model for Industry 4.0 implementation in a company.

Competitiveness: Evidence from Research conducted by various authors have attempted to establish a connection between Industry 4.0 and the competitiveness of companies especially those involved in manufacturing based op-erations. They have argued that Industry 4.0 triggers changes in business models by affecting how these companies create value, capture value, and offer value to their customers and stakeholders, which in turn leads to improve-ments in their competitive position within their market segments, and ultimately enable them achieve sustainable growth and profitability (Faller \& Feldmúller, 2015; Müller et al., 2017). Hence, to test the relationship between the implementation of Industry 4.0 process management concepts and competitiveness of SMEs, a hypothesis is pro-posed as follows:

H2: The competitiveness of a company is positively 
correlated to its successful implementation of Industry 4.0 pro-cess management models.

Human Resources: The role of the human capital possessed by a company in helping it achieve its corporate and organizational goals, especially with respect to the company being able to successfully achieve digital transfor-mation in its quest to implement Industry 4.0 process management models within its production based activities, has been extensively researched by various researchers both within business and the academic environments (Fettig et al., 2018; Shamim et al., 2016; Sivathanu \& Pillai, 2018). Fettig et al. (2018) argues that "notes that IT-competencies of all industrial job descriptions will increase, and in combination with an overall process understanding are necessary factors of success". Hence, to test the relationship between the implementation of Industry 4.0 process management concepts and its human resources, a hypothesis is proposed as follows:

H3: The human resources possessed by a company have a positive influence on its ability to successfully implement Industry 4.0 process management models.

Operations: In general, Industry 4.0 particularly focuses on how digital technologies are adopted and implemented within operations focused processes of a company such as its manufacturing, supply chain and logistics related business processes. The need for adoption and implementation of these technologies is informed by a desire to achieve process optimization in ways that would enable improvements in processes, reduce wastages, reduce turna-round time, achieve lower cost efficiency and ultimately lead to improvements in returns on investments (RoI), thereby leading to sustainable long-term growth for the company (Ford, 2015; Müller et al., 2017; Oesterreich \& Teuteberg, 2016). Therefore, it is a widely held belief within the research community that successful implementation of Industry 4.0 process management model within the operations segment of a company will ultimately lead to sus-tainable growth and profitability for the overall business. Hence, to test the relationship between the implementation of Industry 4.0 process management concepts within a company's operations business processes and its profitability, a hypothesis is proposed as follows:

H4: Adopting and implementing the appropriate digital technologies within the operations processes of a company leads to positive outcomes in successful implementation of Industry 4.0 process management models.

Organisational Structure: Fettig et al. (2018) comment that organizational structure plays a critical role in supporting the successful implementation of Industry 4.0 concepts and principles in the processes of a business entity. Fettig et al. (2018) conceptualizes the organizational structure to include - corporate strategy, work organization, and human resources. They argue that beyond technology, the process organization and structure are a key factor that contributes and determines the overall success of achieving process management improvements that lead to successful Industry 4.0 compliance for the organization. A corresponding hypothesis is proposed to test the validity of this claim as follows:

H5: A well aligned organizational structure positively complements the adoption and implementation of the appropriate digital technologies for specific processes/business units, positively correlated to its successful imple-mentation of Industry 4.0 process management models (Figure 1).

\section{Methodology}

A mixed methodological approach that involved both quantitative and qualitative methods was adopted for the research. The qualitative aspect involved extensive desk research and review of literature from both industry and the academia considered relevant to the subject area of the study, this was part of the process involved in developing the conceptual framework, it led to the identification of factors proposed and investigated by other researchers who had investigated related phenomena and considered

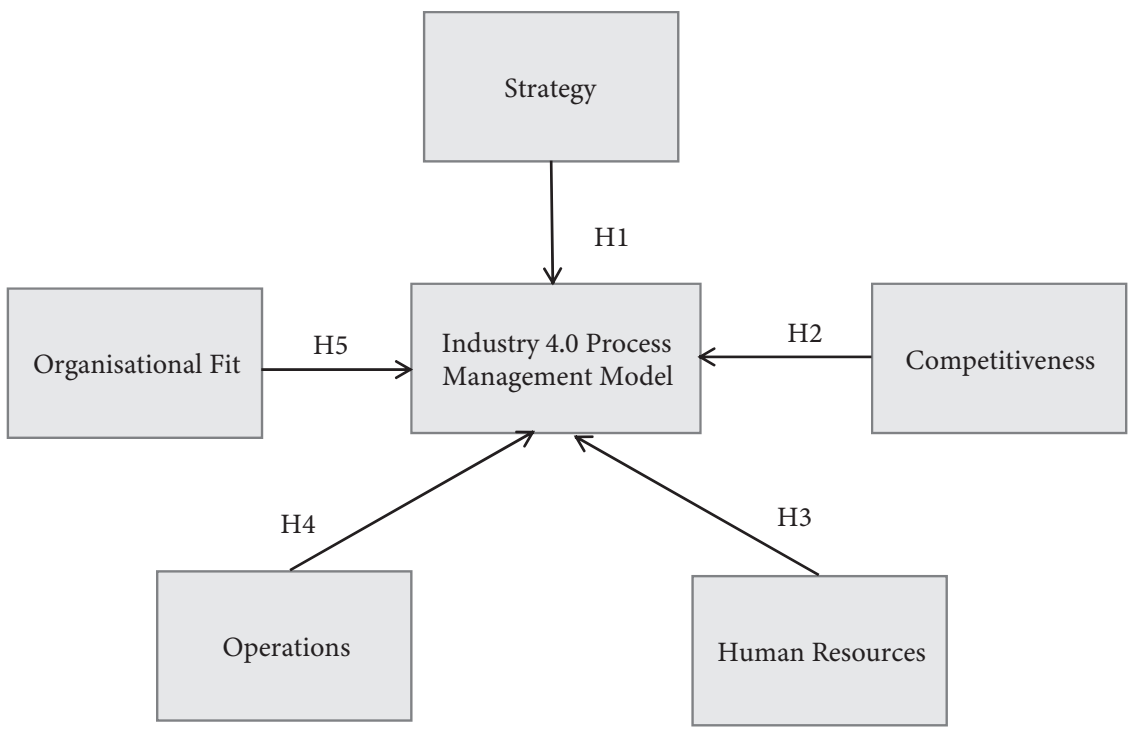

Figure 1. Proposed conceptual framework for Industry 4.0 Process Management Model 
relevant as part of factors needed to achieve an efficient process management model relevant to Industry 4.0 concepts implementation in SMEs based in the manufacturing sector of an economy. For the purpose of the literature review and desk research, an important criteria used in selecting the literature that were reviewed was that they were peer-reviewed literature indexed in major scientific database such as Ebscohost, ERIH Plus, Web of Science, Scopus, and Google Scholar. Also, business related articles from industry sources such as major consultancy firms such as Accenture, KPMG, PwC etc. were also included considering the major research efforts these companies have devoted to subject areas such as digitalisation, and Industry 4.0. Using a set of key words such as Industry 4.0, digital transformation, SMEs, and process management models; the search yielded a substantial amount of articles from both business and academic sources. The keywords were combined in various search inputs that led to various data outputs. Pre- and post-qualification criteria was used in filtering the results of the literature search output to narrow it down to literature that specifically meets the criteria to be included in the study. The findings of the systematic literature review were instrumental in developing the proposed conceptual framework.

For the quantitative methodological research, an online questionnaire was used in collected data, the data collection was done over a three-month period. Data collection was focused on SMEs based in the manufacturing sector in the Czech Republic. The questionnaire was sent to the targeted respondents via email. The survey questionnaire instru-ment was developed in the English language, and subsequently translated to the Czech language because of the language barrier faced by many of the prospective respondents. A purposive sampling technique was employed in selecting respondents, this was necessary to ensure that the respondents met particular profiles in terms of the posi-tions occupied by them in their various companies. For selecting respondents, two criteria were employed: firstly, that the companies covered were SMEs based in the manufacturing sector within the Czech Republic; secondly, that the respondents were of management cadre, a total of 2 respondents were surveyed per company, this led to a 134 companies being included in the data gathering exercise. The rationale for 2 respondents per company was to ensure that we got a second opinion on the state of affairs in the companies covered. At the conclusion of the data collec-tion exercise, a total of 268 respondents had completed the survey questionnaire. For the data analysis, the statisti-cal method of confirmatory factor analysis - CFA (Harrington, 2008; Wood, 2008) was used in the testing of the measures of a construct included in the proposed conceptual framework, to verify their consistency with the nature of the constructs. The quantitative aspect of the analysis was useful in providing a response to the second research question on how do the constructs in the proposed conceptual framework rank in their level of importance in ena-bling the SMEs achieve their Industry 4.0 process management model implementation.

\section{Results of data analysis}

Firstly, the conceptual framework for the research was developed based on extensive review of relevant literature, this was useful in identifying factors in the constructs that were subsequently measured using a survey questionnaire and confirmatory factor analysis statistical tests. This was necessary in addressing the research question - "what are the relevant factors that enable the implementation of efficient process management model in SMEs that aim to achieve a higher level of Industry 4.0 compliance within their operations and manufacturing processes". A total of five hypotheses were analysed according to the data gathered through the questionnaire. The summary of the results of the structural relationships shows which of the hypothesis were accepted and which were rejected. The questionnaire was administered to the respondents through the use of an electronic form created on the Google online documents platform, this was necessary in order to gather a higher number of responses that is geographically dispersed to businesses in such a way that not restricted to particular geographical areas or regions of the Czech Republic.

The respondents were of different levels of seniority within their respective companies, a deliberate effort was made to ensure that the respondents' position within the companies covered were of management cadre and higher. The respondents were required to provide answers to questions presented to them through the use online questionnaire on a scale between 1 (the weakest) to 5 (strongest), the data gathered through the questionnaire was analysed through the Confirmatory Factor Analysis (CFA). The CFA enabled the researchers to analyse the relationship between the variables of the proposed conceptual framework based on the underlying definition of the questionnaire. The results from the CFA showed the most important factor that determined the result of the questionnaire. The following factors were analysed in the statistical program: Strategy (stra), Competitiveness (comp), Human Resources (hr), Operations (opera), Organisational Fit (orgfit) and Industry 4.0 Process Management Model (pmm). The data analysis based on the CFA shows the statistical weight that these factors have based on the questions as contained in the questionnaire administered to the respondents.

\subsection{Descriptive statistical analysis}

A total of 268 respondents completed the survey questionnaire, with more female respondents than males, the age bracket of respondents was from 25 - over 65 years old, and cuts across all cadres of staff in all the organisations where the data was collected. The table below gives the descriptive analysis of the survey data. 
Table 3. Descriptive statistics of pilot study

\begin{tabular}{|l|l|c|c|}
\hline Demographic & \multicolumn{1}{|c|}{ Group } & Frequency & Percentage \\
\hline \multirow{5}{*}{ Age } & $25-34$ & 80 & 29.9 \\
\cline { 2 - 4 } & $35-44$ & 25 & 9.3 \\
\cline { 2 - 4 } & $45-54$ & 26 & 9.7 \\
\cline { 2 - 4 } & $55-64$ & 47 & 17.5 \\
\cline { 2 - 4 } & 65 and above & 90 & 33.6 \\
\hline \multirow{4}{*}{ Gender } & Male & 119 & 44.4 \\
\cline { 2 - 4 } & Female & 149 & 55.6 \\
\hline \multirow{5}{*}{$\begin{array}{l}\text { Position in } \\
\text { company }\end{array}$} & Junior staff & 86 & 32.1 \\
\cline { 2 - 4 } & Supervisor & 52 & 19.4 \\
\cline { 2 - 4 } & Team leader & 7 & 2.6 \\
\cline { 2 - 4 } & Manager & 43 & 16 \\
\cline { 2 - 4 } & $\begin{array}{l}\text { Senior } \\
\text { manager }\end{array}$ & 72 & 26.9 \\
\cline { 2 - 4 } & Director & 8 & 3 \\
\hline \multirow{3}{*}{ Company size } & Small & 60 & 45 \\
\cline { 2 - 4 } & Medium & 74 & 55 \\
\hline
\end{tabular}

\subsection{Measurement model}

Four common measures were employed in the assessment of the overall model fit, they are: Goodness-of-fit (GFI), normed chi-square (CMIN/DF), Comparative fit index (CFI), and the Root Mean Square Error of Approximation (RMSEA). The values required for these models to certify the model as having a sufficiently good fit are as follows: GFI $\geq 0.90$, CMIN/DF $<3, \mathrm{CFI} \geq 0.95$, and RMSEA $\leq 0.07$ (Joreskog \& Sorbom, 2006; Rigdon \& Hoyle, 2006). A "good measurement model" was achieved by performing an analysis of the model fit indices, standardised regression weights, standardised residual covariance estimates, and covariance modification indices. The measurement model was further verified through the examination of the convergent validity, discriminant validity, and internal consistency (see Table 3). The standardised factor loading has a range of 0.79 to 0.99 which is well above the 0.5 cutoff requirement, while the Average Variance extracted (AVE) values for each construct were also above the required threshold of 0.5 (Joreskog \& Sorbom, 2006; Rigdon \& Hoyle, 2006). The Discriminant validity was met as all square roots of the AVE for each factor were greater than the inter-construct correlations. Finally, the values for composite reliabilities were all above 0.90 which exceeded the required cutoff of 0.70 , therefore demonstrating internal consistency.

\subsection{Structural model}

The model fit of the structural model was good (GFI 0.902, CMIN/DF - 1.753, CFI - 0.985, RMSEA - 0.053). The results of the Path analysis reveals that five out of the seven structural hypotheses required support. The results also showed that significant positive relationships exist between stra and pmm (confirming H1), hr and pmm (confirming $\mathrm{H} 3$ ), and between opera and pmm (confirming $\mathrm{H} 4)$. Also, Table 4 presents the validity of the measures, while Table 5 presents the results of the structural relationship.

Table 4. Validity measures

\begin{tabular}{|l|c|c|c|c|c|c|c|}
\hline \multicolumn{7}{|c|}{ Discriminant Validity } \\
\hline $\begin{array}{c}\text { Cons- } \\
\text { truct }\end{array}$ & CR & AVE & stra & comp & hr & opera & orgfit \\
\hline stra & 0.910 & 0.772 & 0.879 & & & & \\
\hline comp & 0.949 & 0.861 & 0.548 & 0.928 & & & \\
\hline hr & 0.955 & 0.877 & 0.697 & 0.705 & 0.936 & & \\
\hline opera & 0.989 & 0.967 & -0.018 & 0.405 & 0.123 & 0.983 & \\
\hline orgfit & 0.975 & 0.952 & 0.532 & 0.717 & 0.577 & 0.538 & 0.976 \\
\hline
\end{tabular}

Note: $\mathrm{CR}=$ composite reliability, AVE = average variance extracted, stra $=$ strategy, comp $=$ competitiveness, orgfit $=$ organi sational fit, $\mathrm{hr}=$ human resources, $\mathrm{pmm}=$ process management model, opera = operations, square root of AVE is shown in italics at diagonal.

Also, it was observed that there exists a significant negative relationship between orgfit and pmm (confirming $\mathrm{H} 5)$. On the contrary, there was no significant relationship observed between comp and pmm (rejecting H2). Four significant constructs justified a value of $67 \%$ variance in behavioural intention.

\section{Discussions}

This study had as its focus, the identification of critical success factors that aid the attainment of efficient process management models compliant with Industry 4.0 concepts in SME manufacturing sector of the Czech Republic.

Table 5. Summary of results of structural relationships

\begin{tabular}{|c|c|c|c|c|c|c|}
\hline \multirow[b]{2}{*}{ Hypothesis } & \multirow[b]{2}{*}{ Structural Path } & \multirow[b]{2}{*}{ Proposed Effect } & \multicolumn{3}{|c|}{ Estimates } & \multirow[b]{2}{*}{ Result } \\
\hline & & & SRW & t-Value & p-Value & \\
\hline $\mathrm{H} 1$ & stra $\rightarrow$ pmm & + & 0.281 & 4.298 & 0.000 & Supported \\
\hline $\mathrm{H} 2$ & comp $\rightarrow$ pmm & + & 0.080 & 1.209 & 0.227 & Rejected \\
\hline $\mathrm{H} 3$ & $\mathrm{hr} \rightarrow \mathrm{pmm}$ & + & 0.387 & 8.790 & 0.000 & Supported \\
\hline $\mathrm{H} 4$ & opera $\rightarrow$ pmm & + & 0.218 & 3.700 & 0.000 & Supported \\
\hline H5 & orgfit $\rightarrow$ pmm & - & -0.220 & -3.951 & 0.000 & Supported \\
\hline
\end{tabular}

Note: SRW = standardised regression weight, square root of AVE is shown in italics at diagonal. 
Based on the extensive review of relevant literatures, several factors where identified which formed the basis of the conceptual model that was adopted for the research. Factors such as organisational strategy, competitiveness, hu-man resources, operations, and organisational structure were identified based on the synthesis of previous scientific research outputs on related subject areas (De Carolis et al., 2017; Ganzarain \& Errasti, 2016b; Long, Zeiler, \& Bertsche, 2016; Mrugalska \& Wyrwicka, 2017; Müller et al., 2018). successful transition to Industry 4.0 compliant process management models requires a level of organisational integration of many parts of a company's production based IT systems alongside other digital technologies, this integration forms the basis of process digitisation which is anchored on a high level of data analytics maturity of entire value chains. However, due to resource constraints, Industry 4.0 transition for SME manufacturers may proceed in stages with digitisation of certain areas of operations that are most vital to the company's core strategies. Hence, the transition to lean-digitised manufacturing system is a viable business strategy for successful transition Industry 4.0 process management models.

Results from this studies makes it evident that factors organisational strategy, human resources, operations, and organisational fit, which are clearly internal and within the controls of the company are particularly essential and must be prioritised because they ultimately determine the overall competitiveness of the company within its industry segment. Hence, Industry 4.0 transition for typical SME manufacturers must be in line with their organisational, operational and technical particularities. Therefore, the digitisation of certain operations and processes, when aligned with the company's core strategies, capabilities and procedures, can offer superior competitiveness, this implies that the strategic plan for successful Industry 4.0 transition must be contextualised to each particular manufacturer. The process of digitally transforming the manufacturing processes of a company can have profound implications be-cause it has the potential to alters inter- and intra-organisational relationships, lead to job losses among low-skilled workforce, and raises data security and privacy concerns (Morteza, 2019). This makes it imperative for SMEs inter-ested in Industry 4.0 transition to take responsibility for the unintended consequences of the digitisation process and ensure that it proceeds in a manner that simultaneously guarantees economic, social and environmental sustainabil-ity.

\section{Conclusions}

In this paper, an analysis of factors that have impact on determining successful implementation of Industry 4.0 compliant process management models was conducted. This was done with the aim of identifying factors that have significant impact on determining successful outcomes as against those that do not necessarily make any difference to the implementation. It is pertinent to note that there are significant differences in how SMEs implement new processes especially those reliant on digital technologies when compared to larger companies. Due to the fact that Industry 4.0 requires a high number of business processes to be changed and replaced by new ones this causes the SMEs to face different challenges while implementing this new system such as manpower; investments in emerging technologies related to ICTs and IT systems. Evidence obtained from the literature review shows that a lot of research activities is currently ongoing in order to make determine what makes for successful implementation of digital technologies within the operating models of SMEs, still few of them have been able to fully attain Industry 4.0 standards. Hence, this research has identified several successful factors that enable the implementation of efficient process management model in SMEs.

Through two different analyses, qualitative and quantitative in this research, we analysed the main factors that if implemented and correctly managed can lead to a successful implementation of management model of industry 4.0. Based on evidence from the literature review, it is possible to point out the main influencing factors that highly affect the correct implementation. The study of Mittal et al. (2018) gives a clear understanding on how organisational fit affects the challenges faced by the SMEs. Also there are other factors that are considered to be highly connected, that deeply affects the level of difficulty encountered during implementation; the importance of a company's competitiveness in the market in order to offer the latest technology (Competitiveness); the impact new technologies have towards the different process of manufacturing logistic and supply chain (Operations); human resources level of preparation and readiness (Human Resource); new organisation strategies adopted from the companies in order to have a faster and easier implementation of Industry 4.0 (Strategy) and Organisational Fit (Chromjakova, 2017; Faller \& Feldmuller, 2015; Ganzarain \& Errasti, 2016; Müller et al., 2017; Rodič, 2017). From the literature review, it was shown that all the five factors have impact towards the process management model implementation, due to different levels of importance that they show toward it.

According to these conclusions gathered from the qualitative research of this paper, it was then continued with the quantitative research where the creation of a questionnaire gave a clear understanding of what the importance of these factors is toward the process management model. After all the results were gathered then a Confirmatory Factor analysis where all the data collected through a statistical program were possible to be analysed according to the factors gathered in the qualitative research. According to the results it is observed the high dependency and importance of Human Resources towards the Process Management Model. In different tests it is perceived that the factor of PMM (process management model) is of high importance and relevance as it follows all the rules of the statistical tests.

However, from the statistical analysis, it was established that factors such as strategy, human resources, operations, and organisational fit are positively correlated 
and significantly important in achieving successful implementation of Industry 4.0 compliant process management models in SMEs, whereas competitiveness of the firm was not positively correlated hence the corresponding hypothesis was rejected.

From the results of this study, it is evident that for successful transition to an Industry 4.0 compliant process management model (PMM), then the factors identified as critical to success must be prioritised. Getting the company's Human Resources is instrumental in achieving its Industry 4.0 transition objectives, and it shows the high importance that the correct training and readiness of the HR plays as a catalyst for an easier and successful transition towards Industry 4.0. Radical change is always difficult and a major challenge for organisations irrespective of their size, but when a company requires to maintain its competitive position in its market segment, then it has no choice than to continue reinventing itself in ways that would ensure it stays ahead of the competition. To conclude this paper, it is important to state that our aim was to identify critical success factors that aid the attainment of efficient process management models compliant with Industry 4.0 concepts in manufacturing based SMEs, this was reasonably achieved through the result of data analysis carried out as part of the research which showed that organisational strategy, human resources, organisational fit and operations were very instrumental in achieving an Industry 4.0 compliant process management model for manufacturing based SMEs.

The research is limited in scope because of the fact that it was focused on SMEs in the Czech Republic. It would be interesting to have a similar study that is transnational and comparative in nature which would assess the situation between two or more countries. Also, the conceptual model adopted for the research would benefit from being more elaborate to take into consideration other factors that have been researched or suggested by other researchers who have investigated similar areas of research interests. This would be beneficial as it would touch on other areas that may also be critical determinants of success or failure. Hence, future research that takes into considerations these shortcomings is proposed.

\section{Funding}

The research is supported by funding provided for IGA/ FaME/2018/005 - Process management model proposal for implementation of Industry 4.0 in SMEs.

\section{Disclosure statement}

This research paper does not have any competing financial, professional or personal interests from other parties.

\section{References}

Aris, N. M. (2007). SMEs: building blocks for economic growth. Journal of Department of Statistics.
Baena, F., Guarin, A., Mora, J., Sauza, J., \& Retat, S. (2017). Learning factory: the path to Industry 4.0. Procedia Manufacturing, 9, 73-80. https://doi.org/10.1016/j.promfg.2017.04.022

Chromjakova, F. (2017). Process stabilization-key assumption for implementation of Industry 4.0 concept in industrial company. Journal of Systems Integration.

Dassisti, M., Giovannini, A., Merla, P., Chimienti, M., \& Panetto, H. (2018). An approach to support Industry 4.0 adoption in SMEs using a core-metamodel An approach to support Industry 4.0 adoption in SMEs: a core-metamodel and applications. In Annual Reviews in control. Elsevier.

https://doi.org/10.1016/j.arcontrol.2018.11.001

De Carolis, A., Macchi, M., Negri, E., \& Terzi, S. (2017). A maturity model for assessing the digital readiness of manufacturing companies. In H. Lödding, R. Riedel, K.-D. Thoben, G. von Cieminski, \& D. Kiritsis (Eds.), Advances in production management systems. The path to intelligent, collaborative and sustainable manufacturing (pp. 13-20). Cham: Springer International Publishing.

https://doi.org/10.1007/978-3-319-66923-6_2

Dilberoglu, U. M., Gharehpapagh, B., Yaman, U., \& Dolen, M. (2017). The role of additive manufacturing in the era of Industry 4.0. Procedia Manufacturing, 11, 545-554. https://doi.org/10.1016/j.promfg.2017.07.148

DIN. (2016). German standardization roadmap: Industry 4.0. German Standarization Roadmap Industry 4.0 Version 2, 77. http://www.din.de/blob/65354/f5252239daa596d8c4d1f24b40e4486d/roadmap-i4-0-e-data.pdf

Faller, C., \& Feldmúller, D. (2015). Industry 4.0 learning factory for regional SMEs. In Procedia CIRP, 32, 88-91.

https://doi.org/10.1016/j.procir.2015.02.117

Fettig, K., Gačić, T., Köskal, A., Kühn, A., \& Stuber, F. (2018). Impact of Industry 4.0 on organizational structures. In 2018 IEEE International Conference on Engineering, Technology and Innovation (ICE/ITMC) (pp. 1-8). https://doi.org/10.1109/ICE.2018.8436284

Ford, M. (2015). Industry 4.0: Who benefits? SMT: Surface Mount Technology, 30(7), 52-55.

Ganzarain, J., \& Errasti, N. (2016a). Three stage maturity model in SME's towards industry 4.0. Journal of Industrial Engineering and Management, 9(5), 1119-1128.

https://doi.org/10.3926/jiem.2073

Ganzarain, J., \& Errasti, N. (2016b). Three stage maturity model in SME's towards Industry 4.0. Journal of Industrial Engineering and Management, 9(5), 1119-1128.

https://doi.org/10.3926/jiem.2073

Gilchrist, A. (2016). Introducing Industry 4.0. In Industry 4.0 (pp. 195-215). https://doi.org/10.1007/978-1-4842-2047-4_13

Ginevičius, R., \& Ostapenko, A. (2015). A quantitative evaluation of the company environment for the formation of its effective expansion strategy. Intelektine Ekonomika, 9(2). https:// search.proquest.com/docview/1992363358? accountid=15518

Gubán, M., \& Kovács, G. (2017). Industry 4.0 conception. Acta Technica Corviniensis - Bulletin of Engineering, 10(1), 111114. https://search.proquest.com/docview/1869485942?acco untid $=15518$

Harrington, D. (2008). Use of confirmatory factor analysis with multiple groups. Confirmatory Factor Analysis. Oxford Scholarship Online. https://doi.org/10.1093/acprof:oso/9780195339888.003.0005

Hofmann, E., \& Rüsch, M. (2017). Industry 4.0 and the current status as well as future prospects on logistics. Computers in Industry, 89, 23-34. https://doi.org/10.1016/j.compind.2017.04.002 
Joreskog, K. G., \& Sorbom, D. (2006). Recent developments in structural equation modeling. Journal of Marketing Research, 19(4), 404-416. https://doi.org/10.2307/3151714

Kopp, J., \& Basl, J. (2017). Study of the readiness of Czech companies to the industry 4.0. Journal of Systems Integration, (3).

Lee, J., Bagheri, B., \& Kao, H. A. (2015). A Cyber-Physical Systems architecture for Industry 4.0-based manufacturing systems. Manufacturing Letters, 3, 18-23. https://doi.org/10.1016/j.mfglet.2014.12.001

Lee, J., Kao, H. A., \& Yang, S. (2014). Service innovation and smart analytics for Industry 4.0 and big data environment. In Procedia CIRP, 16, 3-8. https://doi.org/10.1016/j.procir.2014.02.001

Li, L. (2017). China's manufacturing locus in 2025: With a comparison of "Made-in-China 2025" and "Industry 4.0". Technological Forecasting and Social Change, 135 (October 2018), 66-74. https://doi.org/10.1016/j.techfore.2017.05.028

Long, F., Zeiler, P., \& Bertsche, B. (2016). Modelling the production systems in industry 4.0 and their availability with highlevel Petri nets. IFAC-PapersOnLine, 49(12), 145-150. https://doi.org/10.1016/j.ifacol.2016.07.565

Lu, Y. (2017). Industry 4.0: A survey on technologies, applications and open research issues. Journal of Industrial Information Integration, 6, 1-10. https://doi.org/10.1016/j.jii.2017.04.005

Meissner, H., Ilsen, R., \& Aurich, J. C. (2017). ScienceDirect Analysis of control architectures in the context of Industry 4.0. Procedia CIRP, 62, 165-169.

https://doi.org/10.1016/j.procir.2016.06.113

Mittal, S., Khan, M. A., Romero, D., \& Wuest, T. (2018). A critical review of smart manufacturing "Industry 4.0 maturity models": Implications for small and medium-sized enterprises (SMEs). Journal of Manufacturing Systems, 49, 194-214. https://doi.org/10.1016/j.jmsy.2018.10.005

Morteza, G. (2019, January 1). Corporate survival in Industry 4.0 era: the enabling role of lean-digitized manufacturing. Journal of Manufacturing Technology Management, 31(1), 1-30. https://doi.org/10.1108/JMTM-11-2018-0417

Mrugalska, B., \& Wyrwicka, M. K. (2017). Towards lean production in industry 4.0. In Procedia Engineering, 182, 466-473. https://doi.org/10.1016/j.proeng.2017.03.135

Müller, J. M., Buliga, O., \& Voigt, K.-I. (2017). Fortune favors the prepared: How SMEs approach business model innovations in Industry 4.0. Technological Forecasting and Social Change, 132 (July 2018), 2-17. https://doi.org/10.1016/j.techfore.2017.12.019

Müller, J. M., Buliga, O., \& Voigt, K.-I. (2018). Fortune favors the prepared: How SMEs approach business model innovations in Industry 4.0. Technological Forecasting and Social Change, 132, 2-17. https://doi.org/10.1016/j.techfore.2017.12.019

Oesterreich, T. D., \& Teuteberg, F. (2016). Understanding the implications of digitisation and automation in the context of Industry 4.0: A triangulation approach and elements of a research agenda for the construction industry. Computers in Industry, 83 (December 2016), 121-139.

https://doi.org/10.1016/j.compind.2016.09.006

Oreoluwa, R. (2011). Small and medium scale enterprises and economic growth in Nigeria: An assessment of financing options. Pakistan Journal of Business and Economic Review, 2(1).

Petrasch, R., \& Hentschke, R. (2016). Process modeling for industry 4.0 applications: Towards an industry 4.0 process modeling language and method. In 2016 13th International Joint Conference on Computer Science and Software Engineering, JCSSE 2016. Khon Kaen, Thailand. https://doi.org/10.1109/JCSSE.2016.7748885
Pfohl, H.-C., Yahsi, B., \& Kuznaz, T. (2015). The impact of Industry 4.0 on the supply chain. Proceedings of the Hamburg International Conference of Logistic (HICL)-20, (August), 32-58.

Phillips, P., \& Raby, S. (2017). Small and medium-sized enterprises. In Contemporary Issues in Strategic Management. https://doi.org/10.4324/9781315674827

Porter, M. E., \& Kramer, M. R. (2006). Strategy \& society: The link between competitive advantage and corporate social responsibility. Harvard Business Review. https://doi.org/10.1108/sd.2007.05623ead.006

Rigdon, E. E., \& Hoyle, R. H. (2006). Structural equation modeling: concepts, issues, and applications. Journal of Marketing Research, 34(3), 412-415. https://doi.org/10.2307/3151904

Rodič, B. (2017). Industry 4.0 and the new simulation modelling paradigm. Organizacija, 50(3), 193-207. https://doi.org/10.1515/orga-2017-0017

Sanders, A., Elangeswaran, C., \& Wulfsberg, J. (2016). Industry 4.0 implies lean manufacturing: Research activities in industry 4.0 function as enablers for lean manufacturing. Journal of Industrial Engineering and Management, 9(3), 811-833. https://doi.org/10.3926/jiem.1940

Schönsleben, P., Fontana, F., \& Duchi, A. (2017). What benefits do initiatives such as industry 4.0 offer for production locations in high-wage countries? In Procedia CIRP, 63, 179-183. https://doi.org/10.1016/j.procir.2017.03.356

Schumacher, A., Erol, S., \& Sihn, W. (2016). A maturity model for assessing Industry 4.0 readiness and maturity of manufacturing enterprises. Procedia CIRP, 52, 161-166. https://doi.org/10.1016/j.procir.2016.07.040

Senvar, O., \& Akkartal, E. (2018). An overview to industry 4.0. International Journal of Information, Business and Management, 10(4), 50-57. https://search.proquest.com/docview/21 10240866 ? accountid $=15518$

Sevinç, A., Gür, Ş., \& Eren, T. (2018). Analysis of the difficulties of SMEs in industry 4.0 applications by analytical hierarchy process and analytical network process. Processes, 6(12). https://doi.org/10.3390/pr6120264

Shamim, S., Cang, S., Yu, H., \& Li, Y. (2016). Management approaches for Industry 4.0: A human resource management perspective. In 2016 IEEE Congress on Evolutionary Computation, CEC 2016. https://doi.org/10.1109/CEC.2016.7748365

Sivathanu, B., \& Pillai, R. (2018). Smart HR 4.0 - how industry 4.0 is disrupting HR. Human Resource Management International Digest. https://doi.org/10.1108/HRMID-04-2018-0059

Sung, T. K. (2018). Industry 4.0: A Korea perspective. Technological Forecasting and Social Change, 132, 40-45.

https://doi.org/10.1016/j.techfore.2017.11.005

Taiwo, M. A., Ayodeji, A. M., \& Yusuf, B. A. (2018). Impact of small and medium enterprises on economic growth and development. American Journal of Business and Management, 1(1), 18-22. https://doi.org/10.11634/21679606170644

Türkeș, M. C., Oncioiu, I., Aslam, H. D., Marin-Pantelescu, A., Topor, D. I., \& Căpușneanu, S. (2019). Drivers and barriers in using industry 4.0: a perspective of SMEs in Romania. Processes, 7(3). https://doi.org/10.3390/pr7030153

Van Scoter, D. J. (2011). Enterprise system implementation projects: A study of the impact of contextual factors on critical success factors. ProQuest Dissertations and Theses. Oregon State University, Ann Arbor.

https://search.proquest.com/docview/919055934?account id $=15518$

Vrchota, J., Volek, T., \& Novotná, M. (2019). Factors Introducing Industry 4.0 to SMES. Social Sciences, 8(5), 130.

https://doi.org/10.3390/socsci8050130 
Wagner, T., Herrmann, C., \& Thiede, S. (2017). Industry 4.0 Impacts on lean production systems. In Procedia CIRP, 63, 125-131. https://doi.org/10.1016/j.procir.2017.02.041

Wee, D., Kelly, R., Cattel, J., \& Breunig, M. (2015). Industry 4.0 how to navigate digitization of the manufacturing sector. McKinsey \& Company, 1-62. https://doi.org/10.1007/s13398-014-0173-7.2

Wiersema, M. F., \& Bantel, K. A. (1992). Top management team demography and corporate strategic change. Academy of Management Journal. https://doi.org/10.5465/256474

Wood, P. (2008). Confirmatory factor analysis for applied research. The American Statistician, 62(1).

https://doi.org/10.1198/tas.2008.s98
Zhou, K., Liu, T., \& Zhou, L. (2016). Industry 4.0: Towards future industrial opportunities and challenges. In 2015 12th International Conference on Fuzzy Systems and Knowledge Discovery, FSKD 2015 (pp. 2147-2152).

https://doi.org/10.1109/FSKD.2015.7382284

Zwikael, O., \& Globerson, S. (2006). From critical success factors to critical success processes. International Journal of Production Research, 44(17), 3433.

https://doi.org/10.1080/00207540500536921 